At the time the plat was laid out, lots were sold and houses constructed, many of which were financed through the Iowa Central Building and Loan Association, which I am informed, took quite a beating when the development of Emery ended.

Today nearly all the homes which were located there have been removed and the power plant is used only in emergencies. The early organizers of this village had great plans for its development, claiming that because of its more central location it was the proper place for the county seat.

\title{
VALUE OF A COUNTY HISTORICAL UNIT
}

Interest in history, as in all other activities, is subject to fluctuation. There are circumstances and occasions which arouse general interest in it and call for organized leadership. There are times when other interests are so paramount that the records of the past reecive little attention. There are other times in which there seems to be nothing at all doing; times in which the community sinks into a lethargy of boresome routine existence. If this latter condition becomes chronic, the community loses all impetus and pulls its people downward and backward, both as regards its history and perhaps everything else.

It is safe to say that there is no community or county which does not have some means and some occasion for interest in its past and hope for its future. The advantages to the people of a county and to the county of having an organized group of citizens interested in the study, preservation, and writing of local history are such that all unorganized counties should proceed at once to form local societies. A well organized historical group may serve as a center in which to keep alive interest in even ordinary times and to furnish leadership for productive activity in livelier times.

The present calls for activity in every line in every community-in local matters no less than in national 
matters. The life of a community depends upon the community spirit and the nation is the sum of its communities. Each community must be conscious of its own part in state and national progress. The history of the community is the very core of this community spirit. Every county is making history and every county should have a historical society to give it a consciousness of this history. There are notable instances of counties in which historical leadership has been maintained through the years. In others the people have allowed the sense of state pride and local enthusiasm to die down and have lost interest in community life and community interests. The sources which fed the spring of distinctive community life were allowed to dry up and people saw nothing in their own particular part of the county and in their own social life in which to interest themselves. In such places county historical societies became inactive or were forgotten, and are in need of a re-awakening.

There are many opportunities to renew activities and historical interest; to accomplish some notable historical work, establish local museums in which counties can take honest pride. The initiation and the impulse for a county historical society must come from within the county itself. A successful movement is by its very nature spontaneous, and permanent interest can be obtained only by local leadership.

If the historical society in your county is inactive, join others in reviving it for immediate participation in the war history of the county and for the permanent service of the community. If there is no county historical society, join with other like-minded people in organizing one to be a center in which the history of your community and of its men and women will be kept alive. Choose leaders who are able and best fitted to make the history of the community the heritage of all its members and the community as well, and uphold them in their unselfish work. An active and effective historical society in every county of the state should be the 1944 goal. -Indiana History Bulletin. 
Copyright of Annals of Iowa is the property of State of Iowa, by \& through the State Historical Society of Iowa and its content may not be copied or emailed to multiple sites or posted to a listserv without the copyright holder's express written permission. However, users may print, download, or email articles for individual use. 